\title{
KONSEP HUKUM PEMBIAYAAN KONSUMEN DI MASA YANG AKAN DATANG
}

\author{
Oleh: Endang Prasetyawati \\ Fakultas Hukum Universitas 17 Agustus 1945 Surabaya \\ Email: endang_pras@yahoo.com.
}

\begin{abstract}
The purpose of this research is to explain the concept of law of consumer finance in the future, that consumer finance is characterized by Indonesia. The method used is normative legal research (legal research), with the approach of the statute and philosophy. Legal materials used in the study include legal primary, secondary and tertiary and supported with interviews. Legal material is then analyzed in such a way and poured in the form of a diskriptif analysis. The results of this research provide consumer finance law concept bids forward, namely consumer finance are characterized by Indonesia, which are based on religious, humanitarian, nationality, democracy and social justice. Consumer finance law characterized by an Indonesia that regulates the equivalence of the position of consumer finance companies and consumers, legal protection for consumer finance companies as well as consumers, as well as paying attention to process contracts, and dispute resolution with the approach of the conscience, in the form of regulation-level legislation, with the hope of better guarantee legal certainty.
\end{abstract}

Key words: Legal concept, consumer Finance, Future.

\begin{abstract}
Abstrak
Tujuan penelitian ini ialah untuk memamaparkan tentang konsep hukum pembiayaan konsumen di masa yang akan datang, yaitu pembiayaan konsumen yang bercirikan Indonesia. Metode yang digunakan ialah metode penelitian hukum normatif (legal research), dengan pendekatan undang-undang (statute approach) dan pendekatan filsafat (philosophy approach). Bahan hukum yang dipergunakan dalam penelitian ini meliputi bahan hukum primer, sekunder dan tersier dan ditunjang dengan wawancara. Bahan hukum kemudian dianalisis sedemikian rupa dan dituangkan dalam bentuk tulisan secara diskriptif analisis. Hasil penelitian ini memberikan tawaran konsep hukum pembiayaan konsumen ke depan, yaitu pembiayaan konsumen yang bercirikan Indonesia, yaitu berdasarkan religius, kemanusiaan, kebangsaan, demokrasi dan keadilan sosial. Hukum pembiayaan konsumen yang bercirikan Indonesia yang mengatur kesetaraan kedudukan perusahaan pembiayaan konsumen dan konsumen, perlindungan hukum bagi perusahaan pembiayaan konsumen maupun konsumen, serta memperhatikan proses kontrak, dan penyelesaian sengketa dengan pendekatan nurani, dalam bentuk peraturan setingkat undang-undang, dengan harapan lebih memberikan jaminan kepastian hukum.
\end{abstract}

Kata kunci: Konsep Hukum, Pembiayaan Konsumen, Masa depan.

\section{A. Pendahuluan}

Mengingat kebutuhan dana bagi masyarakat terus meningkat, maka muncul bentuk-bentuk penyandang dana selain perbankan. Kehadiran penyandang dana selain perbankan tersebut ditujukan untuk membantu pelaku usaha maupun konsumen dalam rangka memenuhi kebutuhannya. Lembaga penyandang dana selain perbankan tersebut merupakan lembaga penyandang dana yang lebih fleksibel dan moderat dibanding dengan lembaga perbankan, yaitu berupa lembaga keuangan non bank (LKNB) dan lembaga pembiayaan. Lembaga keuangan yang tergolong dalam lembaga keuangan non bank (LKNB) ini, yaitu: lembaga pembiayaan, lembaga perasuransian, lembaga dana pensiun, lembaga pegadaian dan lembaga pasar modal (capital Market).

Salah satu jenis usaha pembiayaan dalam Lembaga pembiayaan,adalah : pembiayaan konsumen (consumers finance). Pembiayaan konsumen merupakan badan usaha yang melakukan kegiatan pembiayaan untuk pengadaan barang berdasarkan kebutuhan konsumen dengan sistem pembayaran angsuran atau berkala oleh konsumen. Masyarakat seringkali 
menganggap lembaga pembiayaan konsumen adalah sewa beli, karena membayar secara angsuran. Lembaga pembiayaan konsumen pada prinsipnya memiliki kesamaan dengan sewa beli karena sama-sama membayar barang konsumen dengan cara angsuran, hanya perbedaannya dalam sewa beli tidak ada pihak ketiga yang ikut serta dalam pembiayaan. (Zaeni Asyhadie, 2005: 121) Kemajuan di bidang teknologi telah memacu perusahaan untuk menghasilkan produk yang semakin canggih dan beragam. Kelebihan-kelebihan atas suatu produk terbaru mendorong masyarakat (konsumen) tergiur untuk memilikinya meskipun barangkali secara finansial dana untuk membelinya tidak mencukupi. Bagi masyarakat kelas menengah ke bawah yang berpenghasilan rendah, hal ini tentu merupakan suatu problem tersendiri. Kondisi inilah yang antara lain menyebabkan tumbuh dan berkembangnya lembaga pembiayaan konsumen sebagai salah satu sumber pembiayaan alternatif untuk memenuhi kebutuhan konsumen atas barang-barang konsumtif yang dibutuhkannya seperti, rumah, mobil, televisi, radio, tape recorder, lemari es, tempat tidur, sepeda motor bahkan juga kebutuhan pokok sehari-hari.

Melalui pembiayaan konsumen, masyarakat yang tadinya kesulitan untuk membeli barang secara tunai, akan dapat teratasi dengan mudah dan cepat. Kemudahan yang diberikan oleh lembaga pembiayaan konsumen melebihi kemudahan yang diberikan oleh bank. Lembaga pembiayaan konsumen memberikan kemudahan, keringanan, pelayanan yang cepat, waktu yang singkat, prosedur yang tidak birokratis dan tidak berbelit-belit. Kondisi tersebut sangat disukai oleh masyarakat, dan membawa suatu resiko. Terciptalah lembaga penyandang dana yang lebih fleksibel dan moderat dari bank, yang dalam halhal tertentu bahkan tingkat resikonya lebih tinggi. (Ade Arthesa dan Edia Handiman, 2006: 248). Resiko tersebut bukan hanya bagi konsumen saja tetapi juga bagi lembaga pembiayaan konsumen. Tidak berarti bahwa bisnis pembiayaan konsumen ini tidak punya risiko sama sekali. Sebagai suatu pemberian kredit, risiko tetap ada. Macetnya pembayaran tunggakan oleh konsumen merupakan hal yang sering terjadi. (Munir Fuady,2002: 161)

Para pihak yang terkait dalam aktivitas pembiayaan konsumen adalah perusahaan pembiayaan konsumen, supplier, dan konsumen. (Ade Maman Suherman, 2004: 267) Perusahaan pembiayaan konsumen memberikan jasa pembiayaan, supplier menyediakan barang yang dibutuhkan, konsumen adalah pembeli barang yang menggunakan jasa pembiayaan itu.

Atas dasar kepemilikannya, perusahaan pembiayaan konsumen dapat dibedakan menjadi 3 (tiga) jenis, yaitu perusahaan pembiayaan konsumen yang merupakan anak perusahaan dari pemasok barang dan jasa yang akan dibeli oleh debitur, perusahaan pembiayaan konsumen yang merupakan satu grup usaha dengan pemasok barang dan jasa yang akan dibeli oleh debitur, dan perusahaan pembiayaan konsumen yang tidak mempunyai kaitan kepemilikan dengan pemasok barang dan jasa yang akan dibeli oleh debitur. ( Sigit Triandaru dan Totok Budi Santoso, 2006 :204)

Pembiayaan konsumen merupakan lembaga hutang piutang yang cukup banyak di masyarakat. Pembiayaan konsumen ada di wilayah provinsi sampai di kecamatan, tetapi juga cukup banyak mempunyai masalah baik dalam tataran filosofis, teoritis maupun normatif.

Pelaksanaan pembiayaan konsumen rentan akan munculnya ketidakadilan baik bagi konsumen maupun perusahaan pembiayaan konsumen. Ketidakadilan tersebut muncul karena belum terakomodasinya berbagai kepentingan dalam pembiayaan konsumen oleh suatu hukum, khususnya dalam hal ini adalah berupa undang-undang. Sebagaimana dipahami hukum merupakan kristalisasi nilai-nilai yang terdapat dalam masyarakat, namun demikian dalam hukum biasanya nilai-nilai tersebut digambarkan sebagai berpasangan, tetapi tidak jarang bersitegang. Nilai-nilai tersebut misalnya: ketertiban dan ketentraman, kepentingan umum dan kepentingan individu, kepastian hukum dan keadilan. Ketiada keserasian dan harmonisasi di antara nilai-nilai tersebut yang terdeskripsikan dalam masyarakat mengganggu tujuan dan jalannya proses penegakan hukum itu sendiri. Fokus utama pertentangan ini terletak pada persoalan bagaimana hukum positif dengan jaminan kepastian dapat mewujudkan nilai-nilai moral, khususnya keadilan yang dijunjung tinggi oleh masyarakat dan bentuk keadilan apakah yang diharapkan dan atau seharusnya menjadi landasan dalam hukum positif. (Endang Sutrisno, 2007: 28)

Pembiayaan konsumen lahir karena adanya asas kebebasan berkontrak. Sumber dari kebebasan berkontrak adalah kebebasan individu, yang memiliki makna bahwa setiap individu memiliki kebebasan berkontrak dan membuat kontrak dengan didasarkan pada adanya asas konsensualisme. Asas konsensualisme menentukan bahwa tanpa adanya kesepakatan dari kedua belah pihak, kontrak yang dibuat dapat 
dibatalkan. Orang tidak dapat dipaksa untuk memberikan sepakatnya. Sepakat yang diberikan dengan paksa disebut dengan contradictio intermini, yang pada dasarnya menunjukkan bahwa adanya paksaan itu sama dengan tidak adanya sepakat. Yang mungkin dilakukan oleh pihak lain adalah untuk memberikan pilihan kepadanya, yaitu untuk setuju mengikatkan diri pada perjanjian yang dimaksud, atau menolak mengikatkan diri pada perjanjian dengan akibat transaksi yang diinginkan tidak terlaksana atau take it or leave it. (Sutan Remy Sjahdeini, 1993: 65)

Kebebasan berkontrak dalam pengertian sebagai kebebasan berkontrak yang murni memiliki arti bahwa para pihak yang kedudukannya seimbang sepenuhnya praktis tidak ada, selalu ada pihak yang lebih lemah dari pihak yang lain. Kondisi di atas, dalam ilmu hukum disebut dengan misbruik van omstandigheden atau penyalahgunaan kesempatan atau penyalahgunaan keadaan. Salah satu keadaan yang dapat disalahgunakan ialah adanya kekuasaan ekonomi (economish overwicht) pada salah satu pihak, yang mengganggu keseimbangan antara kedua belah pihak. Adanya kehendak yang bebas untuk memberikan persetujuan yang merupakan salah satu syarat bagi sahnya suatu persetujuan pada akhirnya menunjukkan tidak ada kehendak yang bebas atau ada kehendak yang cacat.

Perkembangan ekonomi masyarakat yang begitu pesat mengharuskan hukum dapat mengikuti perkembangan tersebut secara seimbang agar dapat mendukung kebutuhan hukum dalam masyarakat. Keterhubungan hukum dan masyarakat tersebut diikuti pula dengan hubungan hukum dan ekonomi yang sering digambarkan bahwa hukum berkejar-kejaran dengan ekonomi. Keadaan tersebut memunculkan kebutuhan akan peraturan-peraturan hukum yang melingkupi semua kegiatan ekonomi, atau yang dimaksud sebagai hukum ekonomi. Saat ini peraturan dalam bidang hukum ekonomi dapat dikatakan masih sangat kurang dan belum memadai, sebagai contoh keberlakuan hukum perjanjian dalam lembaga pembiayaan konsumen.

Seiring dengan meningkatnya transaksi bisnis, baik yang bersifat lokal, nasional, regional maupun global ini sudah barang tentu akan membawa konsekuensi perlunya aturan main (rule of the game) yang berupa regulasi yang dapat menjamin kontinuitas aktivitas dunia usaha itu sendiri secara adil dan pasti. (Ade Maman Suherman, 2004: 1). Demi terciptanya keteraturan dan kepastian dalam mengakomodasi berbagai kepentingan para pelaku bisnis, maka

32 Yustisia Vol.2 No.2 Mei - Agustus 2013 hukum bisnis akan menjadi kebutuhan yang tidak terelakkan sebagai pedoman fundamental.

Fungsi hukum adalah untuk mengatur hubungan antara negara atau masyarakat dengan warganya dan hubungan antar manusia, agar supaya kehidupan di dalam masyarakat berjalan dengan lancar dan tertib. Tugas hukum adalah untuk mencapai kepastian hukum (demi adanya ketertiban) dan keadilan di dalam masyarakat. (Soerjono Soekanto, 1983: 55) Kepastian hukum mengharuskan diciptakannya peraturan-peraturan umum atau kaedah-kaedah yang berlaku umum. Agar supaya tercipta suasana yang aman dan tenteram di dalam masyarakat maka peraturanperaturan termaksud harus ditegakkan serta dilaksanakan dengan tegas.

Lembaga pembiayaan yang lebih fleksibel dan moderat tersebut memerlukan suatu payung hukum dalam menjalankan aktivitasnya, sekaligus untuk mengatasi permasalahan apabila terjadi sengketa di antara para pihak. Lembaga pembiayaan, sampai sekarang hanya diatur dalam:

1). Keputusan Presiden Nomor 61 Tahun 1988 tentang Lembaga Pembiayaan, yang kemudian dicabut dengan Peraturan Presiden Nomor 9 tahun 2009 tentang Lembaga Pembiayaan;

2). Keputusan Menteri Keuangan Republik Indonesia No.1251/KMK.013/1988 tentang Ketentuan dan Tata cara Pelaksanaan Lembaga Pembiayaan juncto Keputusan Menteri Keuangan Repubik Indonesia No. 468/KMK.017/1995 tentang Perubahan Keputusan Menteri Keuangan No. 1251/KMK.013/1988;

3). Peraturan Menteri Keuangan Nomor 84/ PMK.012/2006 tentang Perusahaan Pembiayaan;

4). Peraturan Menteri Keuangan Nomor 30/PMK.010/2010 tentang Penerapan Prinsip Mengenal Nasabah Bagi Lembaga Keuangan Non Bank.

Aturan tersebut hanya merupakan pengaturan secara administratif, sedangkan aturan substantif belum ada. Hal tersebut menimbulkan kesulitan apabila terjadi pelanggaran dari salah satu pihak, karena belum adanya aturan khusus dalam Lembaga Pembiayaan Konsumen.

Aturan hukum yang ada mengenai pembiayaan konsumen selama ini hanya berupa aturan administratif, baik yang berupa Peraturan Presiden dan Keputusan Menteri Keuangan. Aturan Substantif pembiayaan konsumen berdasar pada Buku III Burgerlijk Wetboek/Kitab UndangUndang Hukum Perdata (selanjutnya disingkat KUH Perdata) tentang Perikatan khususnya bersumber pada pasal 1338 ayat (1) KUH Perdata tentang kebebasan berkontrak.

Konsep Hukum Pembiayaan Konsumen .... 
Proses kontrak dalam pembiayaan konsumen seharusnya melalui tiga tahapan yaitu, tahap pra kontrak, tahap kontrak, dan tahap pasca kontrak. Banyak faktor yang dapat memberikan indikasi tentang adanya penyalahgunaan kekuasaan ekonomi, dalam tahap pra kontrak dan tahap kontrak dari pihak perusahaan pembiayaan konsumen sedangkan dalam tahap pasca kontrak perusahaan pembiayaan konsumen dalam posisi lemah. Proses kontrak pembiayaan konsumen yang ada adalah sebagai berikut:

\section{Tahap Pra kontrak}

Kontrak dalam pembiayaan konsumen adalah berbentuk standard contract (kontrak baku). Pada tahap pra kontrak, konsumen sama sekali tidak diperhitungkan. Konsumen tidak mempunyai kesempatan untuk melakukan tawar menawar, begitu juga informasi yang diperoleh oleh konsumen sangat minim.

\section{Tahap Kontrak}

Berlakunya standard contract (kontrak baku) dalam pembiayaan konsumen, mengakibatkan kontrak tersebut banyak sekali mengandung kelemahan-kelemahan. Kelemahan-kelemahan tersebut antara lain, pihak yang disodori kontrak tidak mempunyai banyak kesempatan untuk mengetahui isi kontrak tersebut, apalagi ada kontrak yang ditulis dengan huruf-huruf yang sangat kecil. Beberapa syarat-syarat yang diperjanjikan ada yang tidak masuk akal atau yang tidak patut atau bertentangan dengan konsep perikemanusiaan atau on redelijke contractsvoorwaarden atau unfair contract terms, yang menempatkan pihak konsumen dalam keadaan tertekan atau dwang positie. Munculnya keadaan yang menempatkan konsumen pada kondisi tidak ada pilihan lain kecuali mengadakan kontrak dengan syaratsyarat yang memberatkan, maka terdapat keadaan di mana nilai dan hasil kontrak tersebut sangat tidak seimbang apabila dibandingkan dengan prestasi timbal balik dari para pihak. Misalnya, besarnya denda maupun besarnya bunga yang harus dibayar oleh konsumen.

\section{Tahap pasca kontrak}

Berkaitan dengan tahap pasca kontrak, maka dapat ditunjukkan dengan keadaan saat ini, yang menunjukkan adanya fenomena baru. Fenomena tersebut yaitu melemahnya kedudukan atau posisi perusahaan pembiayaan konsumen. Keadaan tersebut dikarenakan konsumen sudah semakin pandai sehingga mampu memanfaatkan kelemahan-kelemahan pihak perusahaan pembiayaan konsumen. Misalnya Konsumen mempelajari isi kontrak dan konsumen menemukan kelemahan dari isi kontrak yaitu, misalnya, "Yang menggugurkan wanprestasi adalah dikembalikannya satu unit barang", maka yang terjadi konsumen mengembalikan barang dalam keadaan sudah tidak sesuai dengan aslinya, karena bagian-bagian tertentu sudah ditukar. Perusahaan pembiayaan konsumen saat ini juga membutuhkan perlindungan hukum, karena konsumen jaman sekarang tidak bodoh ataupun berada pada posisi yang lemah seperti anggapan selama ini. Menguraikan tahapan dalam kontrak, maka pada tahap pasca kontrak, perusahaan pembiayaan konsumen berada pada posisi lemah, mengingat konsumen saat ini telah pandai bersiasat dan membuat perhitungan-perhitungan untuk keuntungan pribadinya.

Berdasarkan uraian di atas menunjukkan bahwa dalam pembiayaan konsumen bukan hanya konsumen saja yang memerlukan perlindungan hukum tetapi juga perusahaan pembiayaan konsumen. Mengenai perlindungan konsumen, Pemerintah Indonesia telah memberikan pengaturan secara umum melalui Undang-undang Nomor 8 Tahun 1999 tentang Perlindungan Konsumen. Hanya saja pengaturan perlindungan yang diberikan adalah bersifat lebih umum, dan belum menjamin perlindungan hukum bagi para pihak dalam pembiayaan konsumen.

Bentuk jaminan dalam lembaga pembiayaan konsumen seharusnya adalah fidusia, sesuai dengan Undang-undang No. 42 Tahun 1999 tentang Fidusia. Secara eksplisit ketentuan Pasal 11 Undang-undang No. 42 Tahun 1999 tentang Fidusia, menyatakan bahwa: untuk memberikan kepastian hukum pasal tersebut mewajibkan benda yang dibebani dengan jaminan fidusia didaftarkan pada kantor pendaftaran fidusia. Menurut Pasal 14 ayat (3) UU No. 42 Tahun 1999, maka fidusia oleh undang-undang dianggap lahir pada saat yang sama dengan dicatatnya jaminan fidusia dalam buku daftar fidusia. Adapun bukti pendaftaran fidusia yang diterima penerima fidusia sebagai hak memiliki fidusia diserahkan kepadanya dokumen yang disebut sertipikat jaminan fidusia. Fakta empiris yang ada dalam hal pembiayaan konsumen yang objeknya berupa mobil, apabila konsumennya adalah badan hukum, dan pembiayaan dalam jumlah besar, maka bentuk jaminannya beragam. Jaminan tersebut ada 
yang berupa jaminan fidusia dengan tambahan hak tanggungan, jaminan fidusia terhadap aset benda bergerak yang lain (bukan obyek pembiayaan), jaminan cessie dan sebagainya. Tidak adanya keseragaman mengenai jaminan tersebut mencerminkan adanya ketidak pastian sehingga memungkinkan timbulnya persaingan curang. Sesuai dengan Pasal 26 UU No. 42 Tahun 1999, maka pada saat konsumen telah melunasi pinjaman seharusnya, lembaga pembiayaan konsumen memintakan pencoretan jaminan ke kantor pendaftaran fidusia, namun hal ini tidak dilakukan oleh lembaga pembiayaan konsumen sehingga menimbulkan kerugian bagi konsumen.

Hal ini membutuhkan perhatian khusus dalam pembaharuan hukum nasional, guna tercapainya suatu perlindungan hukum bagi para pihak dalam pembiayaan konsumen untuk keadilan, kepastian hukum dan kemanfaatan, serta mengingat pembiayaan konsumen merupakan lembaga utang piutang yang cukup besar di Indonesia, namun belum ada peraturan setingkat undangundang yang memayunginya.

Berdasarkan latar belakang yang diuraikan di atas, maka rumusan masalah yang dikemukakan adalah: Bagaimanakah konsep hukum pembiayaan konsumen yang memberikan rasa keadilan, kepastian hukum dan kemanfaatan di masa yang akan datang?

\section{B. Metode Penelitian}

Penelitian ini menggunakan metode penelitian hukum normatif, yaitu sebagai salah satu kajian yang dikenal umum dalam bidang ilmu hukum untuk mengkaji substansi hukum positifnya secara tekstual (tidak hanya terhadap norma-norma, tetapi juga asas-asas, bahkan nilai-nilai yang terkandung di dalamnya) yang sifatnya memberikan keadilan, kepastian dan kemanfaatan dalam pembiayaan konsumen. (Sugijanto Darmadi, 1988: 66).

Berkaitan dengan jenis penelitian hukum normatif yang menjadi acuan, maka pendekatan yang digunakan, pendekatan undang-undang (statute approach), pendekatan undang-undang digunakan untuk menelaah semua undangundang dan aturan-aturan yang berkaitan dengan pembiayaan konsumen. Pendekatan filsafat (philosophy approach), pendekatan filsafat untuk memperjelas eksistensi dan perkembangan konflik nilai (keadilan dan kepastian) dalam pembiayaan konsumen, sehingga pada akhirnya dapat ditemukan dan dikembangkan konsep hukum yang dicita-citakan (ius constituendum) tentang pembiayaan konsumen yang memenuhi unsur keadilan, kepastian dan kemanfaatan. Bahan hukum yang dipergunakan dalam penelitian ini meliputi bahan hukum primer terdiri dari peraturan perundang-undangan, yang berkaitan dengan pembiayaan konsumen. Bahan hukum sekunder adalah semua publikasi tentang hukum yang bukan merupakan dokumen-dokumen resmi, antara lain, diperoleh dari buku teks, jurnal jurnal, pendapat para sarjana, putusan pengadilan, hasil laporan penelitian dan hasil-hasil seminar/ lokakarya/simposium yang dilakukan oleh para pakar yang terkait dengan pembahasan ( Ronny Hanintijo Soemitro, 1988: 24) tentang pembiayaan konsumen. Bahan hukum tersier diperoleh dari kamus, ensiklopedia, wawancara dan lain-lain. (Soerjono Soekanto dan Sri Mamudji, 2001: 14-15).

Disamping itu dilakukan wawancara dengan pihak-pihak yang terkait, yaitu PT. Federal International Finance dan PT. Adira Finance. Wawancara ini dibutuhkan untuk menjelaskan dan memahami proses bekerjanya hukum yang berlaku (ius operatum) secara kontekstual, termasuk kendala-kendala dan upaya mengatasinya, dalam melindungi para pihak dalam pembiayaan konsumen yang bergerak dalam bidang pembiayaan terhadap, sepeda motor. Proses analisa bahan-bahan hukum dimulai dari peraturan perundang-undangan maupun peraturan lain yang mengatur tentang pembiayaan konsumen dengan cara mencari substansi berupa ketentuan-ketentuan yang mengatur berlakunya kontrak dalam pembiayaan konsumen. Di samping itu proses analisa juga dilakukan terhadap substansi bahan hukum berupa dokumen putusan-putusan pengadilan yang mengatur tentang penyelesaian sengketa tentang kontrak dalam pembiayaan konsumen.

Pengkajian (analisis) dilakukan secara yuridis kualitatif, yaitu analisis hukum yang mendasarkan atau bertumpu pada penalaran hukum (legal reasoning) dan argumentasi hukum (legal argumentation) secara runtut dengan ciri-ciri: (a) positivitas, yakni hukum yang harus memiliki otoritas atau kewenangan; (b) koherensi, hukum harus dilihat dalam kaitannya dengan aspek-aspek lain sebagai tatanan kehidupan masyarakat; (c) keadilan, hukum harus berisi nilai-nilai filosofis yang digunakan untuk mengatur hubungan antarmanusia. (Jazim Hamidi)

\section{Hasil Penelitian dan Pembahasan}

1. Konsep Hukum Pembiayaan Konsumen Yang bercirikan Indonesia

Norma hukum pembiayaan konsumen tidak hanya diharapkan mewujudkan keadilan, 
tetapi juga harus mampu merefleksikan integritas moral. Dalam rangka mewujudkan idealisme tersebut, pembentukan hukum harus disusun dengan menggunakan acuan yang sesuai dengan cita bangsa Indonesia. Pembaharuan hukum harus ditempuh dengan pendekatan yang berorientasi pada kebijakan (policy oriented approach) dan sekaligus pendekatan yang berorientasi pada nilai (value oriented approach). (Barda Nawawi Arif, 2005: 4). Bertolak dari pemikiran tersebut di atas maka penyusunan konsep undangundang hukum pembiayaan konsumen tidak dapat dilepaskan dari kebijakan sistem pembangunan hukum nasional yang berlandaskan Pancasila sebagai nilai-nilai berkehidupan kebangsaan yang dicitacitakan, yang di dalamnya mengandung keseimbangan nilai:

1. moral religius (Ketuhanan)

2. kemanusiaan (humanistik)

3. kebangsaan

4. demokrasi

5. keadilan sosial.

Oleh karena itu dalam upaya menyusun konsep pembaharuan hukum pembiayaan konsumen perlu dilakukan pengkajian dan penggalian nilai-nilai yang hidup di masyarakat yaitu nilai-nilai religius maupun nilai-nilai budaya/adat. Kata "moral" berasal dari bahasa Latin mos jamaknya mores yang berarti kebiasaan dan adat. Secara etimologi, moral berarti nilai-nilai atau norma-norma yang menjadi pegangan bagi seseorang atau suatu kelompok dalam mengatur tingkah lakunya. Moralitas, pengertiannya lebih abstrak yaitu sifat moral atau keseluruhan asas dan nilai yang berkenaan dengan baik dan buruk. (K. Bertens, 2000:7). Moral merupakan aturan mengenai sikap dan perilaku manusia sebagai manusia. Moral menyangkut aturan tentang baik atau buruk, adil tidaknya tindakan, dan perilaku manusia sejauh dilihat dari segi manusia. Norma moral meletakkan dasar dan tolok ukur penilaian atas perilaku seseorang sebagai penghayatan hidupnya atau kaitannya dengan profesi yang diembannya. Moral berkaitan dengan hal-hal yang mempunyai atau dianggap mempunyai konsekuensi serius bagi kesejahteraan, kebaikan, dan kehidupan manusia. Moral merupakan pedoman tingkah laku agar tidak merugikan orang lain. Moral juga merupakan cermin, ekspresi, dan harapan masyarakat mengenai apa yang baik dan apa yang buruk. Moral sebagai norma diharapkan dapat dipatuhi setiap orang tanpa mempedulikan sanksi meski tidak ditetapkan penguasa. Kemauan baik harus dinilai baik pada dirinya sendiri terlepas dari apapun. Kemauan yang baik yaitu syarat mutlak untuk bertindak secara moral. (Immanuel Kant, 1998: 23). Kata moral tersebut banyak kaitannya dengan agama, hukum, termasuk adat. Moral dengan agama mempunyai hubungan erat dalam praktik kehidupan. Motivasi terpenting dan terkuat bagi perilaku moral yaitu agama. Semua perbuatan boleh atau tidak boleh dilakukan karena agama atau adat melarang atau hal itu bertentangan dengan kehendak Tuhan. Apa yang dinyatakan baik oleh agama, hukum, dan adat secara moral akan baik dan sebaliknya, apa yang dinyatakan tidak baik oleh agama, hukum dan adat merupakan perbuatan tercela.

Setiap agama, mengandung ajaran moral, meski mempunyai ukuran yang tidak terlalu berbeda. Keadilan menurut ajaran Islam dapat diartikan sebagai kewajaran. Keadilan menurut ajaran Islam juga harus dilihat dari itikad atau niatnya, kemudian dilihat dari prosesnya dan tujuannya. Karena itu didalam pembiayaan konsumen ketiga hal tersebut harus terpenuhi, begitu juga kewajaran dalam pembiayaan konsumen harus terpenuhi. Misalnya, denda, maupun keuntungan yang diperoleh perusahaan pembiayaan konsumen harus dalam batas kewajaran.

Menurut konteks agama, kesalahan moral yaitu dosa. Artinya, orang beragama merasa bersalah dihadapan Tuhan karena melanggar perintah-Nya. Menurut filsafat moral, kesalahan moral berupa pelanggaran prinsip etis yang seharusnya dipatuhi. Kesalahan moral pada dasarnya adalah sebuah inkonsistensi rasional. Agama sebagai dasar moralitas. Namun demikian, moralitas bukan merupakan monopoli orang beragama. Baik dan buruk tidak hanya dimiliki orang beragama.

Sementara moral dengan hukum memiliki keterkaitan erat. Hukum membutuhkan moral. Pada masa kekaisaran Roma sudah dikenal pepatah quid leges sine moribus. Maksudnya, apa artinya undang-undang jika tidak disertai moralitas. Hukum tidak berarti banyak kalau tidak dijiwai moralitas. Tanpa moralitas, hukum akan kosong. Kualitas hukum sebagian besar ditentukan mutu moralnya. Karena itu, hukum harus diukur dengan norma moral. Moral membutuhkan 
hukum sebagai manifestasi nilai moral. Jika tidak diungkapkan dan dilembagakan akan tidak berarti. Meski demikian, tidak berarti seluruh moral dirumuskan dalam undangundang sebab terdapat perbedaan antara hukum dengan moral.

Usaha untuk melaksanakan hukum guna menegakan keadilan di antaranya meletakkan hukum dalam potensi yang relevan walaupun tidak dapat dilepaskan dari persepsi subjek hukum tentang keadilan sebagai suatu gagasan yang berlaku umum. Hal itu dikatakan karena setiap pribadi memiliki hati nurani yang berperan sebagai instansi moral yang mampu memandang sesuatu sebagai kebenaran atau kesalahan. Axioma itulah yang menjadi dasar bagi Rawls untuk mengasumsikan bahwa ......in a well ordered society, one effectively regulated by a shared conception of justice, there is also a public understanding as to what is just and $u$ njust. Kesamaan asumsi itu yang menjamintegaknya 'a well-ordered society, tetapi sebaliknya a well-ordered society tidak niscava memajukan a shared conception of justice, misalnya ketertiban itu dipaksakan oleh suatu diktatoran. Setiap masyarakat yang normal memiliki perasaan keadilan yang relatif merata terhadap bentukbentuk perilaku yang adil atau tidak adil. Persoalannya adalah dalam masyarakat yang sedang kacau. Rasa keadilan itu mengalami distorsi sehingga apa yang dianggap tidak adil oleh yang satu, dianggap wajar oleh yang lain dan sebaliknya. Keadilan moral tidak saja dituntut oleh konsumen tetapi juga perusahaan pembiayaan konsumen, ketika mengadakan kontrak pembiayaan konsumen.

Kemanusiaan berasal dari kata manusia, yakni makhluk ciptaan Tuhan Yang Maha Esa, yang memiliki potensi, pikir, rasa, karsa dan cipta. Karena potensi ini manusia mempunyai, menempati kedudukan dan martabat yang tinggi. Kata adil mengandung makna bahwa suatu keputusan dan tindakan didasarkan atas ukuran/norma-norma yang obyektif, dan tidak subyektif, sehingga tidak sewenangwenang. Kata beradab berasal dari kata adab, artinya budaya. Jadi adab mengandung arti berbudaya, yaitu sikap hidup, keputusan dan tindakan yang selalu dilandasi oleh nilai-nilai budaya, terutama norma sosial dan kesusilaan/moral. Kemanusiaan yang adil dan beradab mengandung pengertian adanya kesadaran sikap dan perbuatan manusia yang didasarkan kepada potensi budi nurani manusia dalam hubungannya dengan norma- norma dan kebudayaan umumnya. Potensi kemanusiaan dimiliki oleh semua manusia di dunia, tanpa memandang ras, keturunan dan warna kulit, serta bersifat universal. Kemanusiaan yang adil dan beradab bagi bangsa Indonesia bersumber pada ajaran Tuhan Yang Maha Esa yakni sesuai dengan kodrat manusia sebagai ciptaanNya. Hal ini selaras dengan : Pembukaan UUD NRI 1945 alinea pertama dan Pasal 27, 28, 29, 30 dan 31 UUD NRI 1945.

Demokrasi Indonesia harus memihak pada demokrasi sosial, suatu pemihakan politik yang menjunjung tinggi pada cita-cita keadilan dan bukan sekedar kebebasan. Suatu demokrasi yang mencari dan menggalang kekuatan untuk mencapai konsensus politik. Demokrasi bukan masalah prosedural melainkan alat politik untuk menjunjung dan melaksanakan cita-cita kolektif tentang keadilan sosial.

"Dasar demokrasi ekonomi tercantum dalam Pasal 33 UUDNRI 1945, yaitu produksi dikerjakan oleh semua untuk semua di bawah pimpinan atau pemilikan anggota-anggota masyarakat. Kemakmuran masyarakatlah yang diutamakan, bukan kemakmuran orang seorang. Sebab itu perekonomian disusun sebagai usaha bersama berdasar atas asas kekeluargaan. Bangun perusahaan yang sesuai dengan itu ialah koperasi”. (Revrisond Baswir, 2006: 1)

Selain merupakan dasar demokrasi Pancasila, Pasal 33 UUDNRI 1945 juga merupakan konsep keadilan sosial. Pasal 33 UUDNRI memuat ketentuan:

1. Perekonomian disusun sebagai usaha bersama atas asas kekeluargaan.

2. Cabang-cabang produksi yang penting bagi negara dan yang menguasai hajat hidup orang banyak, dikuasai oleh negara.

3. Bumi dan air dan kekayaan alam yang terkandung di dalamnya dikuasai oleh negara dan dipergunakan untuk sebesarbesar kemakmuran rakyat.

4. Perekonomian nasional diselenggarakan berdasar atas demokrasi ekonomi dengan prinsip kebersamaan, efisiensi berkeadilan, berkelanjutan, berwawasan lingkungan, kemandirian, serta dengan menjaga keseimbangan kemajuan dan kesatuan ekonomi nasional.

Bila dicermati isi dari Pasal 33 ayat (4) UUDNRI 1945 tersebut di atas maka 
Indonesia mempunyai sistem demokrasi ekonomi yang mempunyai karakter khusus yaitu adanya pengakuan hak individu dan pengakuan hak komunal/bersama yang seharusnya dijadikan acuan bagi sistem perekonomian nasional. Karena demokrasi ekonomi inilah yang semestinya paling cocok dengan bangsa Indonesia karena sesuai dengan ideologi bangsa dan tujuan bangsa yaitu keadilan sosial bagi seluruh rakyat Indonesia.

Keadilan sosial merupakan kewajiban yang keras, tidak mengusahakan keadilan sosial sama dengan membiarkan ketidakadilan. Bersikap adil merupakan suatu tuntutan moral, dasar moralitas manusia mulai dengan kesediaan untuk selalu bertindak adil. (Franz Magnis Suseno, 1987: 330). Keadilan sosial merupakan keadilan yang pelaksanaannya tergantung dari strukturstruktur proses ekonomis, politis, sosial, budaya dan ideologis dalam masyarakat. Struktur-struktur itu merupakan strukturstruktur kekuasaan dalam dimensi utama kehidupan masyarakat yang susunannya menentukan kedudukan masing-masing golongan sosial, apa yang mereka masukkan dan apa yang mereka peroleh dari prosesproses itu. Masyarakat merupakan proses yang mengalir terus menerus menurut struktur-struktur kekuasaan.

Mewujudkan keadilan sosial bisa jadi mengubah struktur ekonomis, politis, sosial, budaya dan ideologis yang menyebabkan segolongan orang tidak memperoleh haknya sebagaimana yang seharusnya. Ketidakadilan struktural nampak apabila segolongan orang atau kelas-kelas sosial tertentu, tertimpa ketidakadilan. Bila satu kelas dalam keseluruhannya, misalnya konsumen dalam pembiayaan konsumen tidak memperoleh keadilan, maka hal tersebut tidak semata-mata karena sikap pelaku usaha pembiayaan konsumen yang salah, namun juga dipengaruhi oleh struktur-struktur yang menguasai lalu lintas ekonomi nasional bahkan internasional, dan secara tidak langsung juga struktur kekuasaan politik, sosial, budaya dan ideologi yang dianut.

Keadilan sosial dalam konteks Indonesia berasal dari pidato Soekarno pada 1 Juni 1945 dalam sidang BPUPKI yang menyatakan "kesejahteraan sosial" (bukan keadilan sosial) sebagai dasar negara yang keempat. Konsep tersebut dirumuskan kembali oleh Panitia Sembilan yang menghasilkan Piagam Jakarta pada 22 Juni 1945. Konsep kesejahteraan sosial diubah menjadi keadilan sosial dan urutannya dari sila keempat berubah menjadi sila kelima. (Ign Gatut Saksono: 3-4)

Upaya mewujudkan keadilan sosial di Indonesia tercermin dalam Tap MPR No. vIl Tahun 2001 tentang visi Indonesia Masa Depan, yang menyatakan : "visi Indonesia 2020 adalah terwujudnya masyarakat Indonesia yang religius, manusiawi, bersatu, demokratis, adil, sejahtera, maju, mandiri serta baik dan bersih dalam penyelenggaraan negara". Konsep keadilan dan kesejahteraan dalam visi ini dipisah dan dibuat indikatorindikator untuk mengukur tingkat keberhasilannya.

Indikator untuk adil adalah:

1. Tegaknya hukum yang berkeadilan tanpa diskriminasi;

2. Terwujudnya institusi dan aparat hukum yang bersih dan profesional;

3. Terwujudnya penegakan HAM;

4. Terwujudnya keadilan gender;

5. Terwujudnya budaya penghargaan dan kepatuhan terhadap hukum;

6. Terwujudnya keadilan dalam distribusi pendapatan, sumber daya ekonomi dan penguasaan aset ekonomi, serta hilangnya praktek monopoli;

7. Tersedianya peluang yang lebih besar bagi kelompok ekonomi kecil, penduduk miskin dan tertinggal.

Indikator untuk sejahtera adalah:

1. Meluasnya kesempatan kerja dan meningkatnya pendapatan penduduk sehingga bangsa Indonesia menjadi sejahtera dan mandiri;

2. Meningkatnya angka partisipasi murni anak usia sekolah;

3. Terpenuhinya sistem pelayanan umum bagi seluruh lapisan masyarakat termasuk pelayanan kepada penyandang cacat dan usia lanjut, seperti pelayanan transportasi, komunikasi, penyediaan energi dan air bersih.

4. Tercapainya hak atas hidup sehat bagi seluruh lapisan masyarakat termasuk melalui sistem kesehatan yang dapat menjamin terlindunginya masyarakat dari berbagai resiko yang dapat mempengaruhi kesehatan dan tersedianya pelayanan kesehatan yang bermutu, terjangkau dan merata; 
5. Meningkatnya indeks pengembangan manusia yang menggambarkan keadaan ekonomi, pendidikan, dan kesehatan secara terpadu.

6. Terwujudnya keamanan dan rasa aman dalam masyarakat.

Penerapan sila keadilan sosial dan Pancasila terdapat dalam UU No. 25/2000 tentang Program Perencanaan Nasional (Propenas) maupun dalam UU No. 25/2004 tentang Sistem Perencanaan Pembangunan Nasional serta dalam Rencana Pembangunan Jangka Panjang (RPJP) 2005-2025.

Tugas dan tujuan negara untuk mewujudkan keadilan sosial semakin sulit dalam era globalisasi neoliberal karena masyarakat dan ekonomi tumbuh dalam sistem kapitalisme, yang mengakibatkan semakin tampak kesenjangan ekonomi kuat dan ekonomi lemah. Penindasan ekonomi kuat terhadap ekonomi lemah dengan mengambil keuntungan sebesar-besarnya sehingga menimbulkan ketidakserasian dan menimbulkan kecurangan-kecurangan dari masing-masing pihak untuk mendapatkan keuntungan bagi masing-masing pihak tersebut dengan menghalalkan segala cara mengabaikan rasa kemanusiaan.

Sebagaimana yang terjadi dalam kontrak pembiayaan konsumen ternyata beberapa ketentuan yang seharusnya diperhatikan oleh para pihak ternyata diabaikan misalnya:

a. good faith (itikad baik);

b. fair dealing (transaksi yang adil);

Konsep pembiayaan konsumen yang bercirikan Indonesia harus memperhatikan beberapa hal yaitu:

1. Kesetaraan kedudukan perusahaan pembiayaan konsumen dan konsumen.

Sebagaimana diketahui bahwa para pihak tidak hanya terikat oleh ketentuan yang ada dalam perjanjian dan ketentuan undang - undang, tetapi terikat juga oleh itikad baik, moral dan kepatutan. Itikad baik atau bonafides (bahasa Romawi), artinya bahwa kedua belah pihak harus berlaku terhadap yang lain berdasarkan kepatutan di antara orang - orang yang sopan tanpa tipu daya, tanpa tipu muslihat, dan tanpa akal - akalan, tidak hanya melihat kepentingan diri sendiri tetapi juga harus memperhatikan kepentingan orang lain.

Suatu perjanjian/kontrak haruslah dilaksanakan dengan itikad baik, asas itikad baik tertuang dalam Pasal 1338 ayat (3) KUH
Perdata. Menurut Joyodigoeno, itikad baik digunakan pada saat akan membuat perjanjian/ kontrak. Artinya sejak semula para pihak harus mempunyai sikap yang jujur (beritikad baik sudah ada pada mulanya). Orang yang menganggap beritikad buruk maka yang menuduh tersebut harus membuktikannya. (HR. Daeng Naja. 2006:13).Asas moral dan asas kepatutan terdapat dalam Pasal 1339 KUH Perdata. Asas moral adalah faktorfaktor yang memberikan motivasi pada yang bersangkutan untuk melakukan perbuatan hukum berdasarkan pada kesusilaan (moral), sebagai panggilan dari hati nuraninya, sedangkan asas kepatutan berkaitan dengan ketentuan mengenai isi perjanjian.

Berdasarkan ketentuan tersebut di atas maka seharusnya berdasarkan asas itikad baik, asas moral dan asas kepatutan kontrak pembiayaan konsumen memperhatikan kesetaraan kedudukan para pihak dalam perjanjian yang sebenarnya di dalam hukum kontrak juga sudah diatur yaitu yang biasanya disebut dengan asas persamaan hukum. Asas ini menempatkan para pihak di dalam persamaan derajat, tidak ada perbedaan, walaupun ada perbedaan kulit, bangsa, kekayaan, kekuasaan, jabatan dan lain - lain. Masing - masing pihak wajib melihat adanya persamaan ini dan mengharuskan kedua pihak untuk menghormati satu sama lain sebagai manusia ciptaan Tuhan.

Perwujudan kesetaraan kedudukan para pihak dalam hal ini adalah:

a. Hak dan Kewajiban Perusahaan Pembiayaan Konsumen dan Konsumen Memperhatikan hak dan kewajiban perusahaan pembiayaan konsumen maupun hak dan kewajiban konsumen secara proporsional sesuai dengan teori keadilan distributif, sebagaimana telah diuraikan dalam Bab II, bahwa keadilan distributif menuntut setiap orang mendapat apa yang menjadi haknya secara proporsional dan berdasarkan asas keseimbangan dalam kontrak. Asas ini menghendaki kedua pihak memenuhi dan melaksanakan kontrak yang telah dibuat. Asas keseimbangan ini merupakan kelanjutan dari asas persamaan. Perusahaan pembiayaan konsumen mempunyai kekuatan untuk menuntut prestasi dan jika di perlukan dapat menuntut pelunasan prestasi melalui kekayaan konsumen. Perusahaan pembiayaan konsumen 
memikul pula beban untuk melaksanakan kontrak itu dengan itikad baik. Kedudukan perusahaan pembiayaan konsumen yang kuat diimbangi dengan kewajibannya untuk memperhatikan itikat baik, sehingga kedudukan perusahaan pembiayaan konsumen dan konsumen seimbang.

b. Perlindungan hukum terhadap para pihak dalam pembiayaan konsumen :

1) Perlindungan hukum bagi konsumen

Kontrak baku dalam pembiayaan konsumen merupakan kontrak yang telah ditentukan dan telah dituangkan dalam bentuk formulir/ tertulis. Kontrak ini telah ditentukan secara sepihak oleh pihak perusahaan pembiayaan konsumen (kreditur). Penyusun kontrak dalam hal ini perusahaan pembiayaan konsumen mempunyai kedudukan monopoli, perusahaan pembiayaan konsumen bebas dalam membuat redaksinya, sehingga konsumen berada dalam keadaan di bawah kekuasaan kreditur.

Pada kontrak pembiayaan konsumen, kedudukan para pihak tidak seimbang, pihak konsumen tidak berada dalam keadaan yang betul-betul bebas untuk menentukan apa yang diinginkan dalam kontrak. Pihak perusahaan pembiayaan konsumen memiliki posisi lebih kuat dan menggunakan kesempatan tersebut untuk menentukan klausulklausul tertentu dalam kontrak pembiayaan konsumen. Format dan isi kontrak dirancang oleh pihak perusahaan pembiayaan konsumen.

Format dan isi kontrak dirancang oleh pihak yang memiliki kedudukan lebih kuat, maka dapat dipastikan bahwa kontrak tersebut memuat klausul-klausul yang menguntungkan baginya, atau meringankan atau menghapuskan beban-beban atau kewajibankewajiban tertentu yang seharusnya menjadi bebannya yang biasa dikenal dengan klausul eksonerasi. Berdasarkan hal tersebut perlu diberikan perlindungan hukum terhadap konsumen dari tindakan sewenang-wenang perusahaan pembiayaan konsumen.
Guna melindungi konsumen, maka terdapat larangan bagi perusahaan pembiayaan konsumen untuk mengalihkan beban tanggung gugat dari pihak perusahaan pembiayaan konsumen kepada pihak konsumen, setiap kerugian yang timbul di kemudian hari harus tetap ditanggung oleh para pihak yang harus bertanggung gugat berdasarkan klausul kontrak pembiayaan konsumen, kecuali jika klausul tersebut merupakan klausul yang dilarang berdasarkan Pasal 18 UUPK.

Perlu diperhatikan juga perlindungan hukum terhadap konsumen bila terjadi force majeure/keadaan memaksa, misalnya terjadi musibah (gempa bumi). Dasar dari force majeure dalam Pembiayaan konsumen adalah ketentuan yang terdapat di dalam:

1. Pasal 1244 Buku III KUH Perdata:

"Jika ada alasan untuk itu, si berhutang harus dihukum mengganti biaya, rugi dan bunga apabila ia tidak dapat membuktikan, bahwa hal tidak atau tidak pada pada waktu yang dapat dilaksanakannya perikatan itu, disebabkan karena suatu hal yang tidak terduga, pun tidak dapat dipertanggungjawabkan padanya , kesemuanya itupun jika itikad buruk tidaklah ada pada pihaknya."

2. Pasal 1245 Buku III KUH Perdata: "Tidaklah biaya rugi dan bunga, harus digantinya apabila lantaran keadaan memaksa atau lantaran suatu kejadian tidak disengaja si berhutang berhalangan memberikan atau berbuat sesuatu yang diwajibkan atau lantaran halhal yang sama telah melakukan perbuatan yang terlarang."

Berdasarkan rumusan pasal-pasal tersebut di atas, terdapat 3 (tiga) unsur yang harus dipenuhi untuk force majeure yaitu:

1. tidak memenuhi prestasi;

2. ada sebab yang terletak di luar kesalahan yang bersangkutan;

3. faktor penyebab itu tidak diduga sebelumnya dan tidak dapat dipertanggungjawabkan sebelumnya. 
Selain itu dalam suatu force majeure harus dapat dibuktikan oleh orang atau pihak yang bersangkutan mengenai:

1. tidak bersalah;

2. tidak dapat memenuhi kewajibannya dengan cara lain;

3. tidak menanggung resiko. (H.R. Daeng Naja, 2006: 235-236)

Pada fakta pembiayaan konsumen telah terjadi pergeseran konsep force majeure, karena perusahaan pembiayaan konsumen tidak mau tahu dengan keadaan tersebut. Seharusnya ketentuan tentang force majeure disesuaikan dengan ketentuan yang terdapat di dalam Buku III KUH Perdata, dan ketentuan tersebut perlu ditaati.

2) Perlindungan hukum bagi perusahaan pembiayaan konsumen.

Era globalisasi membawa dampak perubahan dalam berbagai hal termasuk kemampuan dan perilaku konsumen. Kondisi tertentu dalam pembiayaan konsumen menunjukkan bahwa ternyata yang membutuhkan perlindungan hukum bukan hanya konsumen tetapi kreditur/ perusahaan pembiayaan konsumen. Hal ini dikarenakan konsumen pada era sekarang lebih kritis dan pandai juga "nakal" (bad debtor). (Richard Hynes). Sebagaimana telah diuraikan dalam bab terdahulu bahwa pada tahap pasca kontrak posisi kreditur adalah lemah. Guna melindungi pihak kreditur/pelaku usaha maka perusahaan pembiayaan konsumen juga perlu menerapkan prinsip-prinsip umum yang berlaku dalam perkreditan. Prinsip umum dalam perkreditan adalah Formula 4P (personality, purpose, prospect, payment) dan Formula 5C (collateral, capacity, character, capital, condition of economy). Secara umum prinsip ini sering disebut sebagai prinsip kehati-hatian (prudential principle). (Hermansyah, 2008: 66). Pembiayaan konsumen seharusnya mengikuti prinsip-prinsip kehati-hatian tersebut walaupun yang digunakan tidak perlu seluruhnya namun sebagian saja yaitu cukup dengan Formula 3P dan formula 4C.

Formula 3P dapat diuraikan sebagai berikut:
1. personality,

Perusahaan pembiayaan konsumen harus mencari data secara lengkap mengenai kepribadian calon konsumen, antara lain mengenai riwayat hidupnya, peri lakunya misalnya apakah dia menjalankan salah satu saja dari Ma 5 (istilah Jawa : Maling, Madon, Madat, Mabuk, Main) yaitu, mencuri, main perempuan, candu/drugs, minuman keras, berjudi. Hal ini perlu diperhatikan karena apabila seseorang melakukan hal tersebut di atas maka kejujuran dan itikad baiknya perlu dipertanyakan.

2. purpose,

Perusahaan pembiayaan konsumen juga harus mencari data tentang tujuan penggunaan barang oleh calon konsumen.

3. payment,

Perusahaan pembiayaan konsumen harus mengetahui dengan jelas mengenai kemampuan dari calon konsumen untuk melunasi hutangnya dalam jumlah dan jangka waktu yang telah ditentukan. berikut:

Formula $4 \mathrm{C}$ dapat diuraikan sebagai

1. character,

Calon konsumen harus memiliki watak, moral dan sifatsifat pribadi yang baik. Penilaian terhadap karakter ini dilakukan untuk mengetahui tingkat kejujuran, integritas dan kemauan dari calon konsumen untuk memenuhi kewajiban dan menyelesaikan pembayaran hutangnya.

2. collateral,

Jaminan untuk sarana pengamanan (back up), atas resiko yang mungkin terjadi atas wanprestasinya konsumen di kemudikan hari, misalnya tidak bisa melunasi utangnya. Jaminan ini diharapkan mampu melunasi sisa utang dan bunganya.

3. condition of Economy,

Kondisi ekonomi secara umum dan pekerjaan/penghasilan dari calon konsumen perlu mendapatkan perhatian dari perusahaan pembiayaan konsumen untuk 
menghindari resiko yang mungkin terjadi yang diakibatkan oleh kondisi ekonomi tersebut.

4. capacity,

Kemampuan konsumen untuk dapat melunasi hutangnya sesuai dengan jumlah dan jangka waktu yang telah ditentukan.

Selain penggunaan prinsip kehatihatian, kreditur/perusahaan pembiayaan konsumen juga harus membina kerja sama antar perusahaan pembiayaan, sehingga bisa saling memberikan informasi tentang bad debtor, karena di dalam praktek pembiayaan konsumen bad debtor biasanya mengulangi perbuatannya dengan berpindah-pindah perusahaan pembiayaan konsumen. Bila ada kerja sama dan saling memberikan informasi tentang bad debtor maka perusahaan pembiayaan konsumen bisa melakukan penghadangan terhadap bad debtor tersebut melalui black list, sehingga tidak terjadi persaingan curang. Sebagaimana yang terjadi di negaranegara lain yaitu Inggris, Pakistan dan Penssylvania, perusahaan pembiayaan konsumen wajib mempunyai sistem komputerisasi sehingga daftar dari bad debtor bisa diketahui oleh semua pihak/ perusahaan pembiayaan konsumen.

\section{Proses kontrak pembiayaan konsumen}

Terdapat 3 (tiga) hal yang perlu diperhatikan di dalam proses pembuatan kontrak yaitu, tahap pra kontrak, kontrak dan pasca kontrak. Tahap pra kontrak di dalam pembiayaan konsumen diawali dengan adanya informasi baik melalui pemasangan spanduk, penyiaran di radio maupun di televisi. Berdasarkan teori kontrak yang dikemukakan oleh van Dunne, tahap pra kontrak harus sudah memperhatikan itikad baik, karena menurut teori ini dasar pengikatan kontrak bukan hanya kepastian hukum namun lebih utama adalah tercapainya keadilan. Sehingga walaupun tanpa kesepakatan secara tertulis maka sudah terjadi pengikatan sehingga apa yang tertuang di dalam brosur ataupun iklan harus sesuai dengan pelaksanaan perjanjian. Sebagaimana yang terjadi di Inggris maupun di Pensylvania, informasi yang diberikan kepada konsumen diawasi dengan ketat agar tidak terjadi penyesatan terhadap konsumen.
Tahap kontrak juga harus beritikad baik yaitu pihak kreditur memberikan kesempatan kepada pihak debitur untuk membaca, mengerti dan memahami isi kontrak. Bila perlu pihak kreditur memberikan penjelasan kepada konsumen tentang hal-hal yang dianggap penting, misalnya hak-hak konsumen. Setelah kontrak ditandatangani salinan kontrak harus diberikan kepada konsumen sebagai arsip konsumen untuk disimpan. Seharusnya diberikan kesempatan kepada konsumen sebagaimana yang terjadi di Inggris, Pakistan dan Pensylvania, untuk dapat membatalkan kontrak dengan syarat-syarat tertentu yang ditentukan oleh kreditur

Tahap pasca kontrak, untuk menghindari adanya berbagai permasalahan setelah terjadinya kontrak maka seharusnya mekanisme kontrak yang ada diikuti dengan benar. Apabila terjadi permasalahan seharusnya diselesaikan melalui jalur yang benar yaitu, jalur hukum.

\section{Penyelesaian sengketa dengan pendekatan nurani}

Kemacetan pembayaran utang yang biasa disebut dengan kredit bermasalah atau nonperforming loan merupakan risiko yang ada dalam pembiayaan konsumen. Risiko tersebut berupa keadaan di mana konsumen tidak dapat membayar angsuran tepat pada waktunya. Kredit bermasalah ini dapat disebabkan oleh beberapa faktor. Misalnya, faktor kondisi ekonomi konsumen, kesengajaan dari konsumen, kelalaian dari para pihak yang terlibat dalam proses kredit, kesalahan prosedur pemberian kredit maupun disebabkan oleh faktor lain seperti kenaikan suku bunga maupun karena overmacht.

Berdasarkan berbagai sebab tersebut di atas maka penyelesaian sengketa akibat adanya pembayaran utang yang tidak tepat atau macet tidak bisa ditangani secara generalisir, namun harus dipilah-pilah sesuai sebab yang ada. Selama ini walaupun di dalam kontrak pembiayaan konsumen tidak selalu tercantum suatu klausul, bahwa "apabila konsumen tidak membayar uang angsuran selama 3 (tiga) bulan maka barang akan ditarik kembali oleh kreditur", namun konsumen sudah tahu akan hal tersebut karena hal itulah yang selalu terjadi. Penyelesaian tersebut seharusnya tidak harus selalu demikian.

Penyelesaian dengan hati nurani yang dimaksudkan di sini adalah bahwa 
harus ada kebijakan-kebijakan tertentu dari perusahaan pembiayaan konsumen untuk menyelesaikan permasalahan secara kasuistis. Misalnya, pembayaran angsuran macet karena konsumen atau mungkin keluarganya sakit atau terkena musibah. Maka seharusnya diadakan perundingan ulang dan kalau mungkin dibuat kontrak baru yang menguntungkan bagi para pihak. Namun bila pembayaran angsuran macet karena konsumen yang "nakal" atau tidak beritikad baik maka dapat diselesaikan secara hukum. Durkheim mengidentifikasi dua jenis hukum, yang kemudian didefinisikan sebagai jenis sanksi yang menjalankannya. Hukum yang represif seperti hukum kriminal, menghukum orang yang bersalah dengan membebaninya hukuman. Hukum restitutif mengandung sanksi yang bertujuan mengembalikan ke kondisi sebelum tindakan melanggar hukum dilakukan. Maka dalam kontrak pembiayaan konsumen, sanksi hukum restitutif dapat dikenakan kepada konsumen "nakal", khususnya yang mengganti/menukar bagian-bagian dari kendaraan bermotor yang asli dengan yang tidak asli/kualitas jelek.

Berdasarkan keadaan tersebut di atas maka agar kontrak pembiayaan konsumen memenuhi unsur keadilan, kepastian maupun kemanfaatan baik bagi konsumen maupun kreditur maka perlu dipikirkan bentuk kontrak pembiayaan konsumen yang sesuai. Konsep yang ditawarkan dalam penulisan ini adalah kontrak dalam bentuk umum dan khusus (genereal Term and Special Term).

a. general Term, adalah kontrak dalam bentuk standard contract (kontrak baku) yang sudah tersedia dalam bentuk tertulis dan berlaku secara umum bagi seluruh konsumen sebagaimana yang sekarang ini sudah dilaksanakan oleh perusahaan pembiayaan konsumen.

b. Spesial Term, adalah kontrak yang dibuat secara khusus tergantung dari keadaan konsumen. Misalnya adanya perundingan baru antara kreditur dan konsumen yang mengharuskan dibuat kontrak baru dengan ketentuan-ketentuan khusus yang hanya berlaku bagi kedua belah pihak saja, yaitu kreditur dan konsumen tertentu.

\section{Simpulan}

Berdasarkan hasil penelitian dan pembahasan dapat disimpulkan sebagai berikut:

Konsep hukum pembiayaan konsumen ke depan, yaitu pembiayaan konsumen yang bercirikan Indonesia, yaitu berdasarkan religius, kemanusiaan, kebangsaan, demokrasi dan keadilan sosial. Hukum pembiayaan konsumen yang bercirikan Indonesia yang mengatur kesetaraan kedudukan perusahaan pembiayaan konsumen dan konsumen, perlindungan hukum bagi perusahaan pembiayaan konsumen maupun konsumen, serta memperhatikan proses kontrak, dan penyelesaian sengketa dengan pendekatan nurani, dalam bentuk peraturan setingkat undangundang, dengan harapan lebih memberikan jaminan kepastian hukum.

\section{d. Saran}

Berdasarkan kesimpulan tersebut di atas saran yang dapat disampaikan adalah sebagai berikut :

1. Kepada badan pembentuk undang-undang ( DPR bersama-sama Presiden):

Segera membentuk peraturan pembiayaan konsumen yang setingkat undang-undang, yang mengatur secara administratif maupun secara substantif dan bercirikan Indonesia.

2. Bagi pelaku usaha yaitu pihak perusahaan pembiayaan konsumen:

a. Perlu diperhatikan di dalam proses pembuatan kontrak yaitu, tahap pra kontrak, kontrak dan pasca kontrak. Tahap pra kontrak harus sesuai dengan pelaksanaan perjanjian.

b. Penyelesaian sengketa/permasalahan secara kasuistis.

3. Bagi konsumen, harus:

a Mengukur kemampuan daya belinya dan beritikad baik, pada pasca kontrak.

b. Bersikap teliti dan kritis selama proses kontrak.

c. Berani melakukan pengaduan kepada lembaga yang berwenang. 


\section{dAFTAR PUSTAKA}

Arthesa, Ade., dan Edia Handiman, Bank dan Lembaga Keuangan Bukan Bank. (Jakarta: Indeks, 2006), hlm. 248

Asyhadie, Zaeni. Hukum Bisnis: prinsip dan pelaksanaannya di Indonesia. Jakarta: Raja Grafindo Persada, 2005

Berten, K. Pengantar Etika Bisnis. Yogyakarta: Kanisius. 2000

Darmadi, Sugijanto. Kedudukan IImu Hukum dalam IImu dan Filsafat. Bandung: Mandar Maju. 1988

Fuady, Munir. Hukum Tentang pembiayaan dalam Teori dan praktek. Bandung: Citra Aditya Bakti. 2002

Hamidi, Jazim. Makna dan Kedudukan Hukum Naskah proklamasi 17 Agustus 1945 dalam Sistem Ketatanegaraan Indonesia. Disertasi Program Pascasarjana Universitas Pajajaran, Bandung

Hartono, Sunaryati. penelitian Hukum di Indonesia pada Akhir Abad ke- 20, Bandung: Alumni, 1994

Naja, HR. Daeng. contract drafting. Bandung: Citra Aditya Bakti. 2006

Hynes, Rychard et.all, The Law and Economics of Konsumer Finance

Rawls, John. A Theory of Justice. Cambridge: Massacussets, Harvard University Press, 1971

Sjahdeini, Sutan Remy. Kebebasan Berkontrak dan perlindungan yang Seimbang Bagi para pihak dalam perjanjian Kredit Bank di Indonesia. Jakarta: Institut Bankir Indonesia, 1993

Soekanto, Soerjono. Beberapa permasalahan hukum dalam kerangka pembangunan di Indonesia, Jakarta: Ul- Press. 1983

Soekanto, Soerjono., dan Sri Mamudji, , penelitian Hukum Normatif suatu Tinjauan Singkat . Jakarta: Raja Grafindo Persada. 2001

Soemitro, Ronny Hanintijo. Metodologi penelitian Hukum dan Jurimetri. Jakarta: Ghalia Indonesia. 1988

Suherman, Ade Maman. pengantar perbandingan Sistem Hukum. Jakarta: Raja Grafindo Persada. 2004 .Aspek Hukum dalam Ekonomi global. Bogor: Ghalia Indonesia

Sunaryo. Hukum Lembaga pembiayaan. Jakarta: Sinar Grafika. 2008

Suseno, Frans Magnis. Etika Jawa, Sebuah Analisa Falsafati tentang Kebijaksanaan Hidup Jawa. Jakarta : Gramedia Pustaka Utama. 1996

Sutrisno, Endang. Bunga rampai Hukum dan globalisasi. Yogyakarta: Genta Press, 2007

Triandaru, Sigit., dan Totok Budi Santoso, Bank dan Lembaga Keuangan Lain. Jakarta: Salemba Empat. 2006 